\title{
A Novel Human TGF- $\beta 1$ Fusion Protein in Combination with rhBMP-2 Increases Chondro-Osteogenic Differentiation of Bone Marrow Mesenchymal Stem Cells
}

\author{
Silvia Claros ${ }^{1,2}$, Gustavo A. Rico-Llanos ${ }^{1}$, José Becerra ${ }^{1,2,3}$ and José A. Andrades ${ }^{1,2, *}$ \\ 1 Laboratory of Bioengineering and Tissue Regeneration (LABRET), Department of Cell Biology, \\ Genetics and Physiology, Faculty of Sciences, Universidad de Málaga, Campus de Teatinos, \\ Málaga 29071, Spain; E-Mails: silviacg@uma.es (S.C.); gustavo.rico@gmail.com (G.A.R.-L.); \\ becerra@uma.es (J.B.) \\ 2 Networking Biomedical Research Center in Bioengineering, \\ Biomaterials and Nanomedicine (CIBER-BBN), Madrid 28029, Spain \\ 3 BIONAND, Centro Andaluz de Nanomedicina y Biotecnología (Junta de Andalucía), \\ Universidad de Málaga, Málaga 29590, Spain
}

* Author to whom correspondence should be addressed; E-Mail: andrades@uma.es; Tel.: +34-952-131872; Fax: +34-952-131937.

Received: 1 May 2014; in revised form: 3 June 2014 / Accepted: 10 June 2014 /

Published: 25 June 2014

\begin{abstract}
Transforming growth factor-beta (TGF- $\beta$ ) is involved in processes related to the differentiation and maturation of osteoprogenitor cells into osteoblasts. Rat bone marrow (BM) cells were cultured in a collagen-gel containing $0.5 \%$ fetal bovine serum (FBS) for 10 days in the presence of rhTGF (recombinant human TGF)- $\beta 1-F 2$, a fusion protein engineered to include a high-affinity collagen-binding decapeptide derived from von Willebrand factor. Subsequently, cells were moderately expanded in medium with $10 \%$ FBS for 4 days and treated with a short pulse of rhBMP (recombinant human bone morphogenetic protein)-2 for $4 \mathrm{~h}$. During the last 2 days, dexamethasone and $\beta$-glycerophosphate were added to potentiate osteoinduction. Concomitant with an up-regulation of cell proliferation, DNA synthesis levels were determined. Polymerase chain reaction was performed to reveal the possible stemness of these cells. Osteogenic differentiation was evaluated in terms of alkaline phosphatase activity and mineralized matrix formation as well as by mRNA expression of osteogenic marker genes. Moreover, cells were placed inside diffusion chambers and implanted subcutaneously into the backs of adult rats for 4 weeks. Histological study provided evidence of cartilage and bone-like
\end{abstract}


tissue formation. This experimental procedure is capable of selecting cell populations from $\mathrm{BM}$ that, in the presence of rhTGF- $\beta 1-\mathrm{F} 2$ and rhBMP-2, achieve skeletogenic potential in vitro and in vivo.

Keywords: stem/progenitor cell; three-dimensional (3D) culture; transforming growth factor-betal (TGF- $\beta 1$ ); bone morphogenetic protein-2 (BMP-2); osteogenesis; chondrogenesis

\section{Introduction}

Adult stem cells from marrow stroma, operationally termed mesenchymal stem cells or marrow stromal cells (MSCs) [1,2], are now being considered for use in a wide range of tissue engineering technologies, and cell or gene therapy strategies, because of their high capacity for self-renewal $[3,4]$, their multipotentiality for differentiation [5-7] and their demonstrable contributions to somatic tissue restoration [8-10]. With respect to the potential for clinical benefit in skeletal disorders, the possibility of using MSCs for bone tissue engineering has been suggested as an alternative strategy and a promising option, since the requirement for new bone in cases of bone loss caused by trauma, age and metabolic or genetic bone diseases is a major clinical and socioeconomic need $[11,12]$.

To generate bone, MSCs need to undergo differentiation into the osteogenic lineage. Although the factors that regulate their ex vivo expansion and promote their osteogenic maturation remain poorly defined, it is now well established that members of the transforming growth factor-beta (TGF- $\beta$ ) family play a prominent role in the development, growth and maintenance of the vertebrate skeleton $[13,14]$. The effect of TGF- $\beta 1$ on the proliferation and osteoblastic differentiation of MSCs in vitro-causing an increase in total cell number, alkaline phosphatase activity (ALP), and calcium content - is well documented [15-17]. Therefore, controlled administration of TGF- $\beta 1$ could represent an emerging tissue engineering technology that may modulate cellular responses to encourage bone regeneration at a skeletal defect size $[18,19]$.

In animal models of osteogenesis, TGF- $\beta 1$ administration has been shown to stimulate osteoblast activity, causing the formation of new woven bone [14,20], and promoting the healing of fractures and skeletal defects $[18,21]$. It is important to note, however, that discrepant effects of TGF- $\beta$ on proliferation and differentiation of MSC populations with osteogenic potential and bone formation have been reported [22]. Overall, the data emphasize that the physiological effects of TGF- $\beta$ on cells of the osteoblast lineage appear to be highly complex and are influenced by the state of commitment and differentiation of the target cells, the cytokine milieu of the microenvironment, and the conditions of culture [22]. Thus, the effect of this growth factor is context-dependent and the apparent discrepant effects of TGF- $\beta$ on proliferation and differentiation of cells with enhanced osteochondrogenic potential as well as on bone formation are probably owing to the manner in which it exerts its effects.

Bone morphogenetic proteins (BMPs) were originally identified by Urist as organic components found in bone matrix that could induce ectopic bone formation [23]. Of these, BMP-2 is one of the most potent osteoinductive cytokines which has been demonstrated to increase cartilage and bone formation in several animal models [24,25]. When cultures of MSCs are treated with BMP-2, these cells commit to the chondrogenic or osteogenic lineage and, depending on culture conditions, mature 
into either chondrocytes or osteoblasts. Furthermore, it has been reported that TGF- $\beta 1$ in combination with BMP-2 strongly enhances ectopic bone formation, with the resulting bone volume being five-fold greater than that induced by BMP-2 alone [14,26].

Our laboratory has successfully developed a three-dimensional (3D) collagen gel culture system in the presence of a recombinant human TGF- $\beta 1$ bearing a collagen-binding domain (rhTGF- $\beta 1-F 2$ ), in which adherent and non-adherent bone marrow (BM) stem cells are selected and expanded in order to obtain cells capable to differentiate into bone and cartilage [27-30]. Differences between rhTGF- $\beta 1-F 2$ and the commercial rhTGF- $\beta 1$ may be due to the slow release of the collagen-binding factor from the collagen fibrillar network to which it is bound, resulting in a longer half-life [27]. Therefore, our previous results suggested that rhTGF- $\beta 1-F 2$, when applied to a collagen matrix as a vehicle and delivery system, could be of advantage in promoting survival, proliferation, and differentiation and colony mineralization of the osteogenic precursor cell population.

The goal of the present study was to complete the characterization of rat BM-derived cells in the 3D culture system and analyze the effects of a pulse of rhBMP-2 for only $4 \mathrm{~h}$ in the chondro-osteogenic differentiation of these cells. We evaluated the expression of mesenchymal, hematopoietic, endothelial and osteogenic-specific markers, ALP activity and calcium content in vitro, and their capacity to differentiate into cartilage and bone tissue when they are ectopically implanted in vivo. Improvement of our 3D collagen culture may lead to isolation, expansion and differentiation of a heterogeneous population of BM-derived cells for use in tissue engineering and regenerative medicine applications.

\section{Results and Discussion}

\subsection{Morphology and Cell Number in 3D (Three-Dimensional) Collagen Culture}

3D culture was formed by a population of smaller round cells evenly distributed and embedded in collagen matrix; the number of cells sharply decreasedc as a consequence of the starvation period for the initial 10 days (Figure 1). Once normal serum conditions were reestablished, the selected cells began to proliferate either in the presence or absence of rhTGF- $\beta 1-F 2$. Nevertheless, the number of cells harvested from rhTGF- $\beta 1$-F2-treated cultures at day 14 and 16 was significantly higher $(p<0.05$ and $p<0.01$, respectively) when compared with controls. In rhTGF- $\beta 1-F 2$-treated cultures induced also with a pulse of rhBMP-2 on day 14 slightly lower cell numbers were obtained, only significantly different compared to control group ( $p<0.05$ at day 16).

Under a phase contrast microscope, these cells cultured with rhTGF- $\beta 1-F 2$ (in absence or presence of rhBMP-2) increased in size and formed well-defined colonies at the end of differentiation period (Figure 2). BM-derived cells cultured under control conditions never formed colonies and presented a different morphology. 
Figure 1. Quantification of DNA content as indication of cell replication. Values represent the means $\pm \mathrm{SD}, n=3 ; * p<0.05, * * p<0.01$.

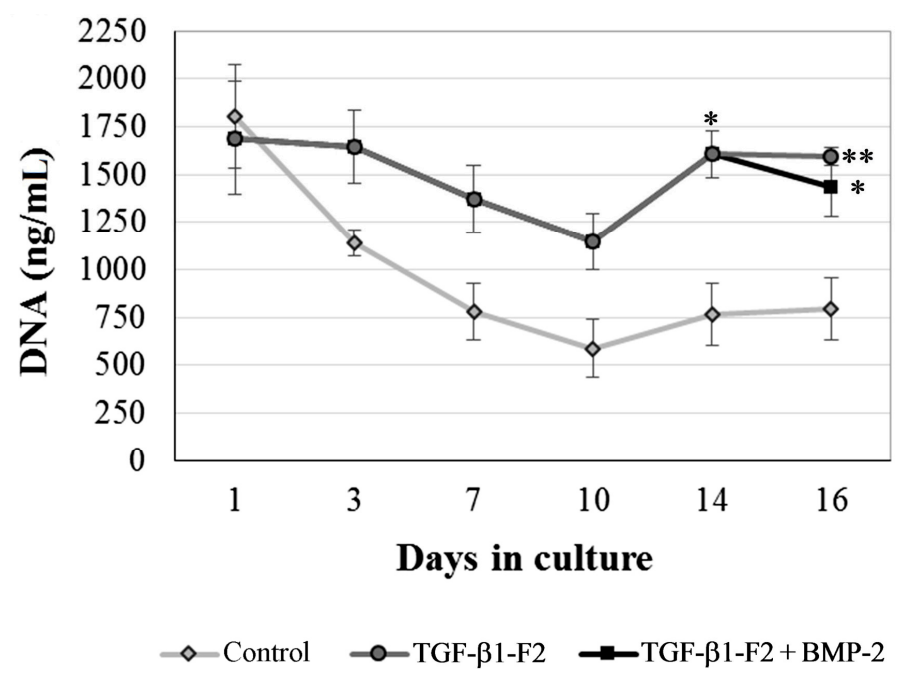

Figure 2. Cell morphology in 3D (three-dimensional) collagen matrix at the end of differentiation period (day 16). (a) Control cultures in the absence of growth factor; (b) Cell cultures in presence of rhTGF- $\beta 1-F 2$; and (c) Cell cultures in presence of rhTGF (recombinant human transforming growth factor)- $\beta 1-\mathrm{F} 2$ and the pulse of rhBMP (recombinant human bone morphogenetic protein)-2. Bars, $200 \mu \mathrm{m}$.

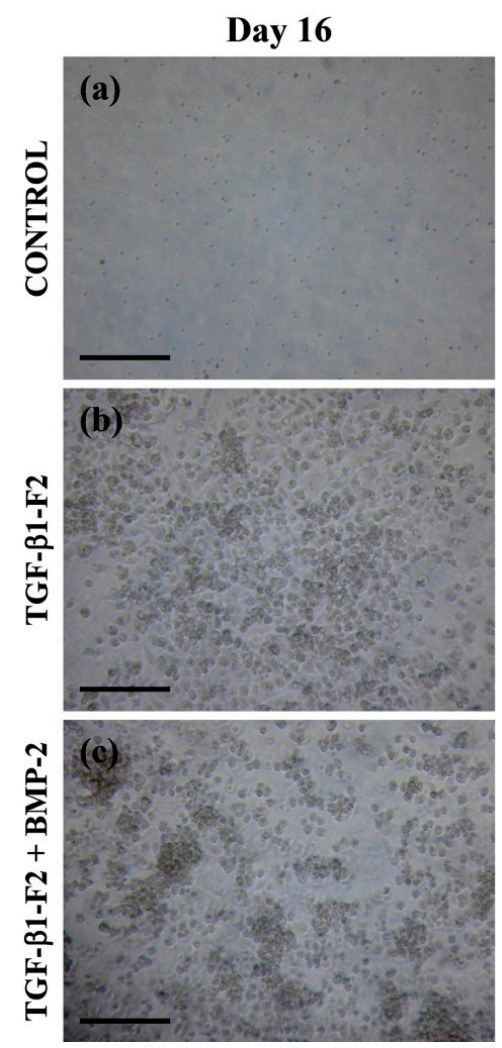

\subsection{Flow Cytometry Analysis of Cells}

ADH (Adherent culture) culture showed the immunophenotype described for MSCs, where most of the cells expressed CD29, CD105, CD166, CD271 and STRO-1, and were negative for CD34, CD45 
(data not shown). However, the profiles of 3D culture revealed a heterogeneous cell population, where positive cells for hematopoietic (CD34, CD45), mesenchymal (CD29, CD105, CD166, CD271, STRO-1), and endothelial markers (CD34, CD133) were found (Figure 3). Comparing 3D cultures at days 10 and $16, \mathrm{CD} 166+$ population decreased over time $(17.5 \%, p<0.05)$, while there was an increase in the expression of some mesenchymal cell markers such as CD29, CD271 and STRO-1 $(+29.2 \%,+25.1 \%,+39.3 \%, p<0.001$, respectively). In addition, the endothelial progenitor cells (EPCs)-like population (CD34+/CD133+/CD45-) decreased significantly $(-14.8 \%, p<0.001)$.

Figure 3. Immunophenotype profiles of 3D culture cells for hematopoietic, mesenchymal and endothelial markers. Representative FACS (fluorescence-activated cell sorting) analysis at days 10 (a) and 16 (b).

\section{(a) Day 10}
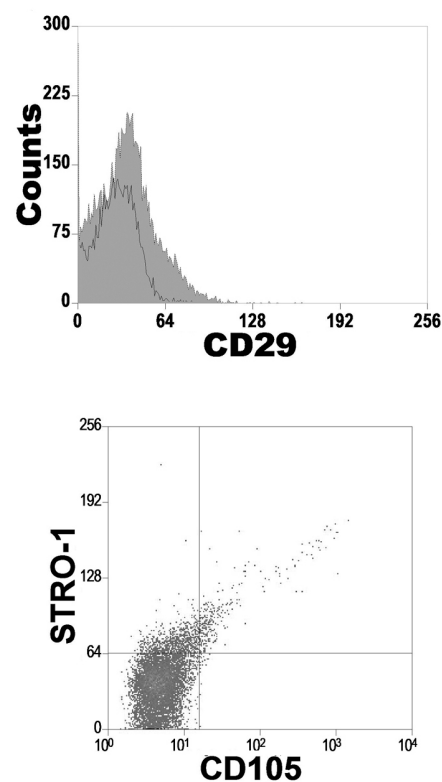

(b) Day 16
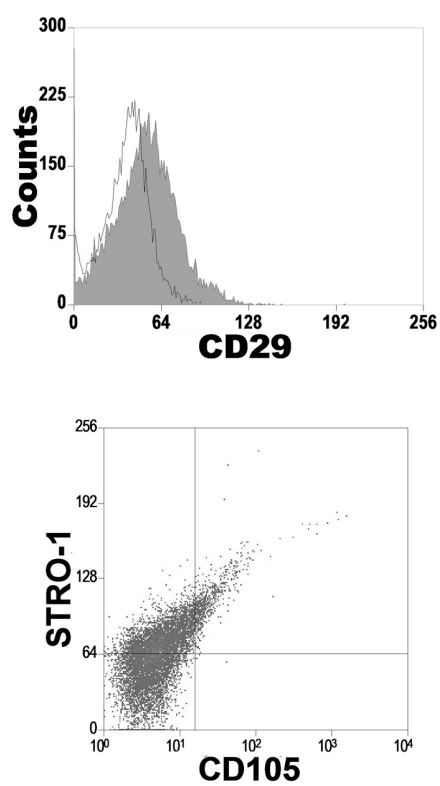
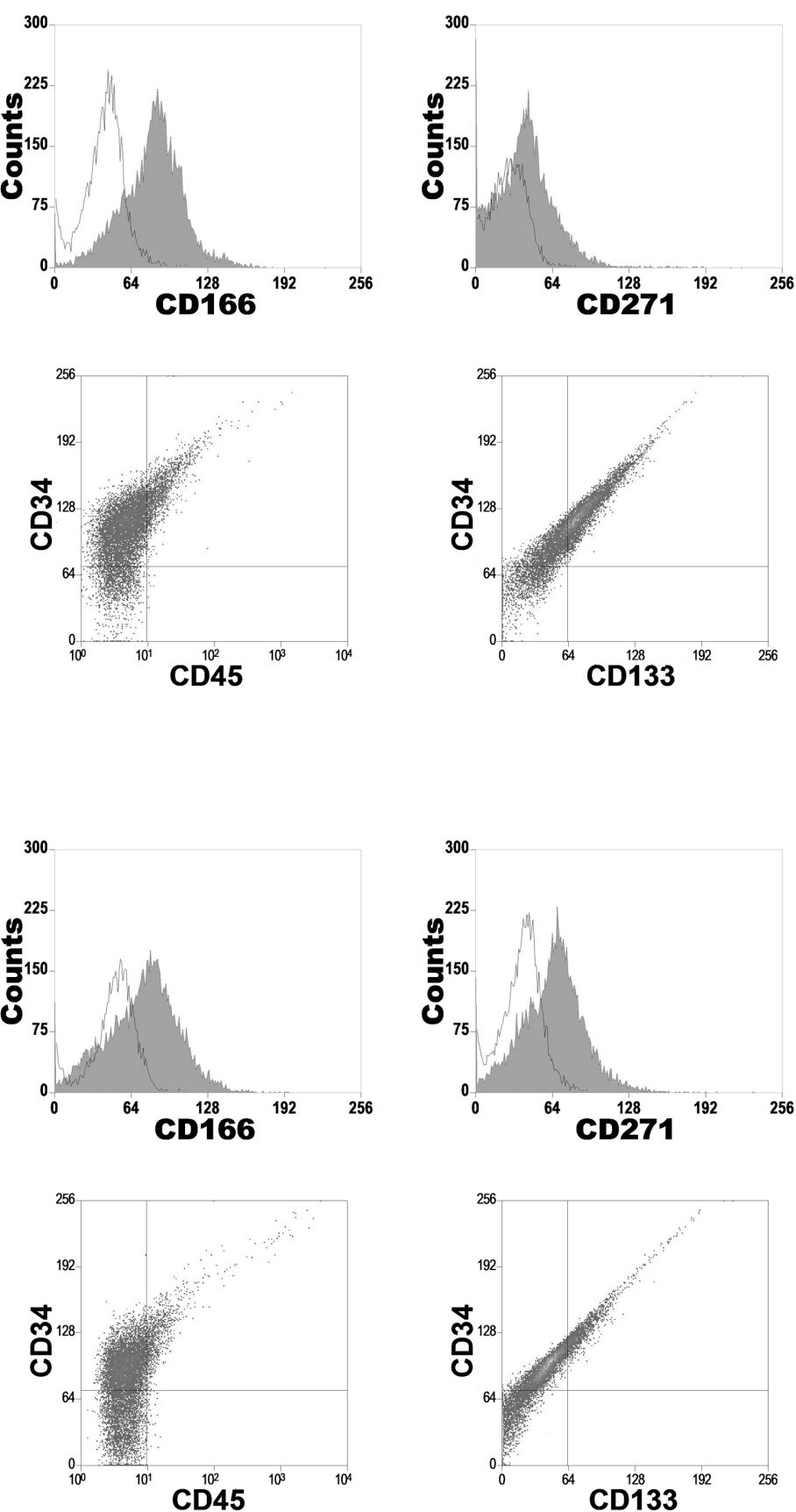


\subsection{Quantitative Real Time RT-PCR (RT-qPCR) Analysis}

Pluripotency of embryonic stem cells is controlled by defined transcription factors, such as Nanog, Oct4 and Sox2. We analyzed the expression of mRNA for these pluripotent specific markers by RT-qPCR at days 10 and 14, and the signal was compared to ADH culture (Figure 4). Nanog, Oct4 and Sox2 were highly expressed in both 3D cultures at days 10 and 14 but was absent in ADH cells $(p<0.001)$. In addition, we evaluated the osteoblastic potential of $3 \mathrm{D}$ culture cells at the end of the differentiation period (day 16), analyzing the expression of mRNA Bsp (Bone sialoprotein), Osx (Osterix) and Oc (Osteocalcin) (Figure 4). Bsp and Osx mRNA displayed the highest expression levels in 3D cultures $(p<0.001 v s$. ADH). Oc mRNA was also detected in 3D culture cells, but its expression level was significantly lower than that found in $\mathrm{ADH}$ cells $(p<0.001)$. Comparison within the 3D culture showed that Osx and Oc mRNA levels were significantly different with or without the pulse of rhBMP-2 $(p<0.01)$. Thus, the osteoblast phenotype was revealed by demonstrating the expression of Bsp, Osx and Oc genes involved in the osteogenic lineage.

Figure 4. mRNA expression in $3 \mathrm{D}$ and $\mathrm{ADH}$ (adherent culture) cultures by quantitative real time RT-PCR (RT-qPCR). rhTGF- $\beta 1-F 2$-treated cells expressed Nanog, Oct4 and Sox2 at the end of selection and amplification period (days 10 and 14, respectively), while ADH cells did not. Moreover, the osteogenic commitment of 3D culture cells at the end of the differentiation period (day 16) was confirmed by the mRNA expression of Bsp (Bone sialoprotein), Osx (Osterix) and Oc (Osteocalcin). The pulse of rhBMP-2 significantly induced further differentiation towards the osteogenic lineage. Values are the means $\pm \mathrm{SD}$, $n=3 ; * * * p<0.001 v s$. ADH culture, $\bullet \bullet p<0.001 v s$. rhTGF- $\beta 1-F 2$.
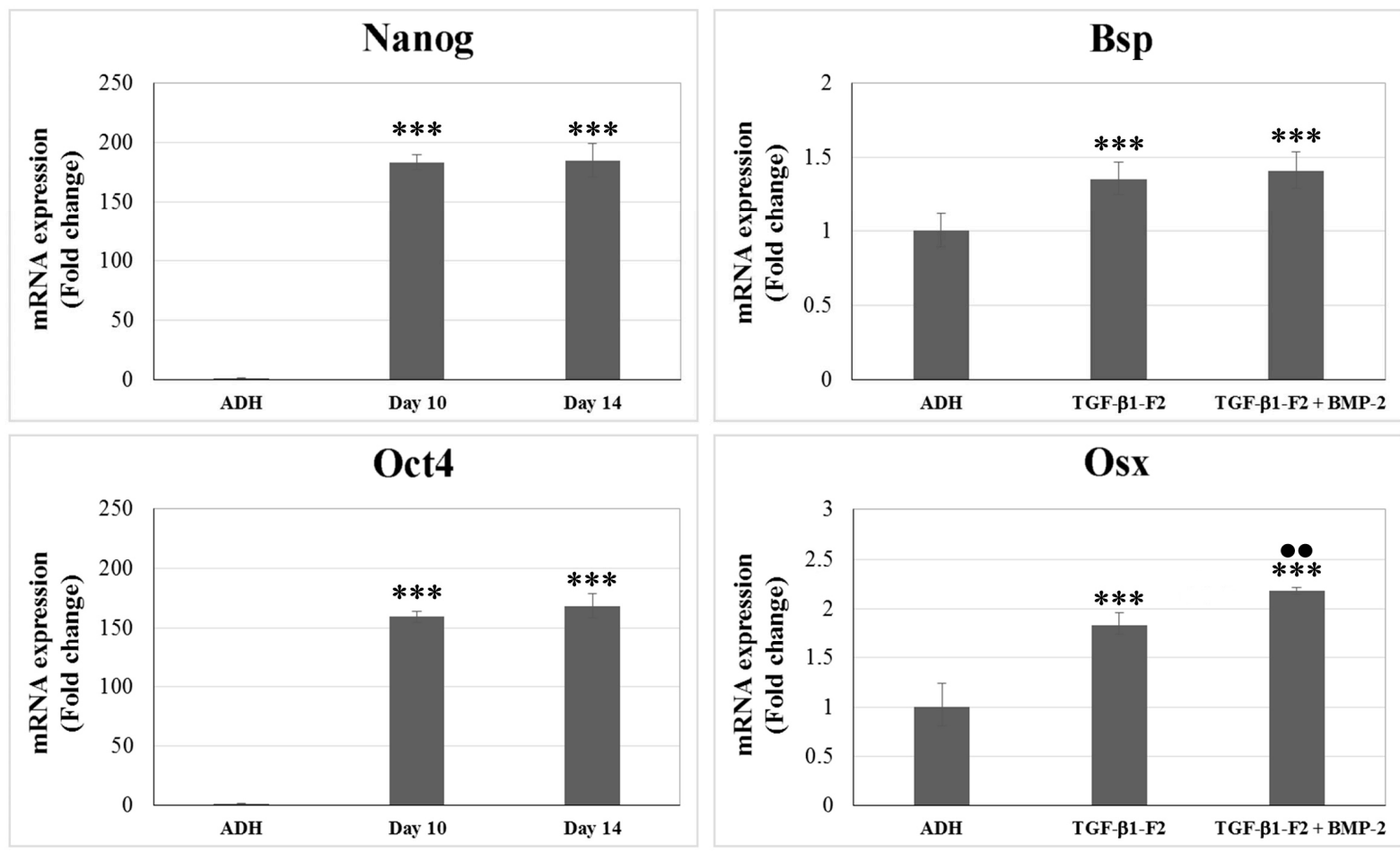
Figure 4. Cont.
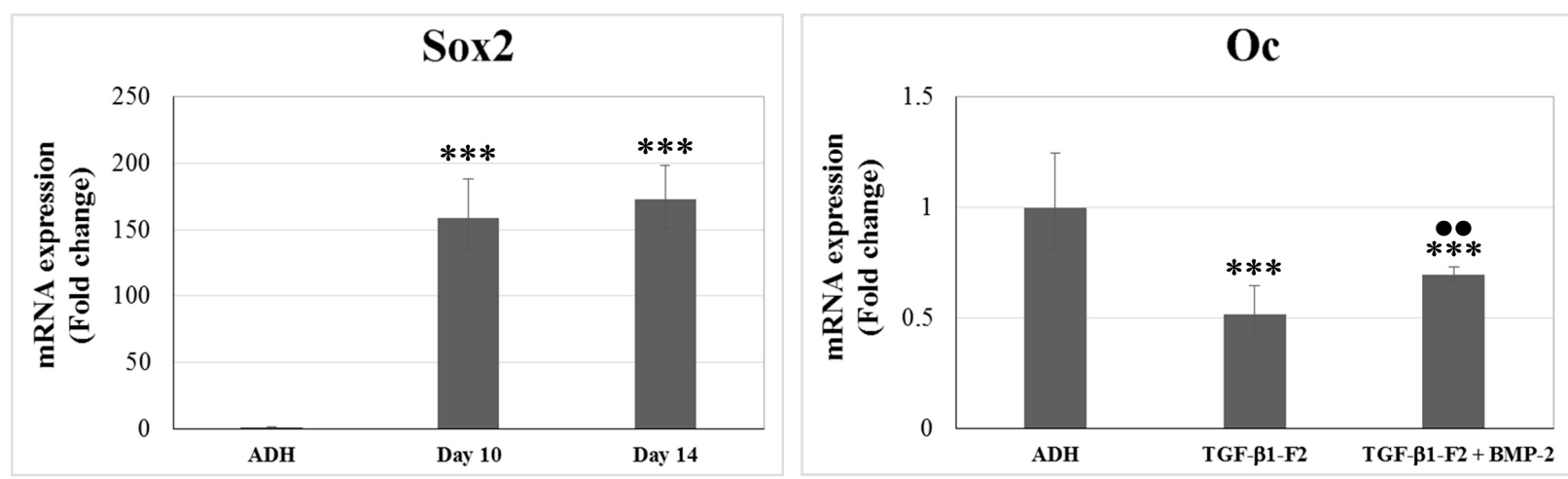

\subsection{Biochemical Assays}

Bone cell differentiation was further confirmed by measuring the ALP specific activity and the amount of calcium deposited. Positive ALP expression was detected only in induced cells, which exhibited significantly higher levels $(p<0.001)$ compared with the controls (Figure 5). At day 14, there were a 14.5-fold difference between control and rhTGF- $\beta 1$-F2-treated cells which rises to 19.3-fold at day 16. Similar levels of ALP activity were observed in cells incubated with rhTGF- $\beta 1-F 2$ and rhBMP-2 (17.4-fold vs. control group at day 16).

Figure 5. Effects of culture conditions on ALP (alkaline phosphatase activity) activity.

Values represent the means $\pm \mathrm{SD}, n=3$; *** $p<0.001$. pNPP: $p$-nitrophenolphosphate.

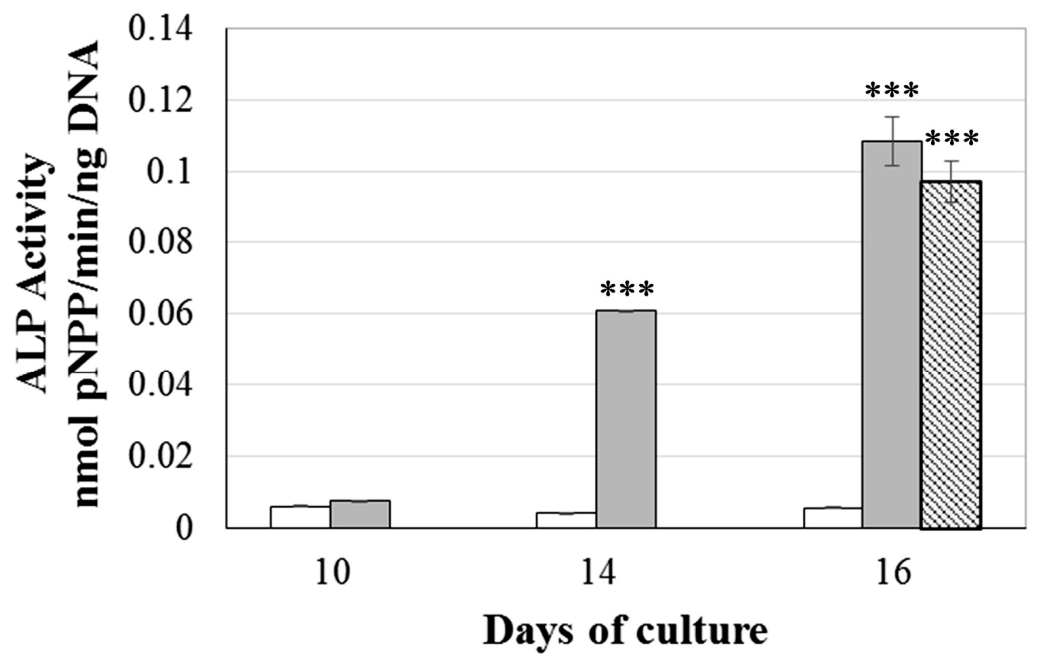

$\square$ Control $\quad \square$ TGF- $\beta 1-F 2 \quad \otimes T G F-\beta 1-F 2+$ BMP-2

Likewise, an important increase in calcium deposition was detected in rhTGF- $\beta 1$-F2-treated cells at day $16(1.74 \pm 0.25 \mathrm{mg} / \mathrm{dL}, p<0.01)$ (Table 1$)$, which was significantly higher in cultures induced also with a pulse of rhBMP-2 $(2.47 \pm 0.21 \mathrm{mg} / \mathrm{dL}, p<0.001 v s$. control and $p<0.05 v s$. rhTGF- $\beta 1-F 2-$ treated cells). 
Table 1. Quantification of calcium content as indication of mineralization.

\begin{tabular}{ccc}
\hline Time (Days) & Treatment & Calcium (mg/dL) \\
\hline \multirow{2}{*}{10} & Control & $0.41 \pm 0.26$ \\
& TGF- $\beta 1-F 2$ & $0.62 \pm 0.37$ \\
\hline \multirow{2}{*}{14} & Control & $0.47 \pm 0.16$ \\
& TGF- $\beta 1-F 2$ & $0.71 \pm 0.23$ \\
\hline \multirow{3}{*}{16} & Control & $0.50 \pm 0.16$ \\
& TGF- $\beta 1-F 2$ & $1.74 \pm 0.25^{* *}$ \\
& TGF- $\beta 1-F 2+$ BMP-2 & $2.47 \pm 0.21^{* * *}$ \\
\hline
\end{tabular}

Values are expressed as the mean $\pm \mathrm{SD}(n=3) . * * p<0.01, * * * p<0.001$.

\subsection{In Vivo Implantation and Histological Study}

One million of 3D cells were implanted into diffusion chambers and harvested after 4 weeks. Histological analysis revealed that control implants were principally filled with loose fibrous connective tissue. Importantly, neither cartilage nor bone is formed in these chambers (data not shown). In contrast, in vivo bone-like tissue formation was demonstrated in rhTGF- $\beta 1-\mathrm{F} 2$ treated cultures (Figure 6a-c). Sections stained with PSH (picrosirius-hematoxyline) (Figure 6a) and Goldner's trichrome (Figure 6b, detail from zone 1) showed dense tissue condensations with osseous matrices localized adjacent to the Millipore filter. Figure 6c show parallel section with negative area for TB (toluidine blue). However, the best results were obtained in chambers with cells induced with rhTGF- $\beta 1-F 2$ and rhBMP-2 (Figure 6d-1). We found several nodules of cartilage and bone-like tissue located near the filters. Cartilage nodules (zone 2) displayed metachromasia when stained with TB (Figure 6e), showed high affinity for AB (alcian blue) (demonstrating the presence of sulfated glycosaminoglycans) (Figure 6f) and were collagen II immunoreactive (Figure 6g), indicating a cartilaginous matrix. In contrast, bone-like condensations near the wall of the chamber (Figure $6 \mathrm{~d}$, zone 3), stained positively with PSH (Figure 6h) and Goldner's trichrome (Figure 6i). We normally distinguished the bone condensation close to the filter, as demonstrated by von Kossa staining (Figure 6j) and type I collagen immunohistochemistry (Figure 61), while cartilage is formed towards the centre of the chamber (metachromasia with TB in Figure 6k).

\subsection{Discussion}

The vast majority of in vitro studies in the regenerative medicine and tissue engineering field are performed in 2-dimensional structures. Researchers have expressed the necessity to develop culture systems that better represent the natural environment of cells in tissues and organs. Therefore, our group has successfully developed a 3D collagen gel culture system [27-30] that allows one to study the isolation, expansion and growth factor responsiveness of BM-derived cells and evaluate the capacity of these cells to undergo differentiation into bone and/or cartilage tissue when implanted in vivo.

In the present study we sought to characterize further BM-derived cells, isolated in the described $3 \mathrm{D}$ collagen gel culture system and exposed to a novel recombinant human TGF- $\beta 1$ fusion protein (rhTGF- $\beta 1-F 2$ ), engineered to contain an auxiliary collagen-binding domain. Besides, we investigated 
whether the combination of rhTGF- $\beta 1-\mathrm{F} 2$ and rhBMP-2 enhances the differentiation of MSCs towards the chondro-osteogenic lineage.

Figure 6. Histological sections of diffusion chambers with $3 \mathrm{D}$ culture cells after 4 weeks of in vivo implantation. Different types of tissue can be observed, according to cell type implanted. Asterisks $(*)$ represent filters of the chambers. (a-c) rhTGF- $\beta 1$-F2-treated cultures induced with a pulse of rhBMP-2. In vivo bone-like tissue formation was demonstrated. (a) PSH (picrosirius-hematoxyline); (b-c, details from zone 1) Goldner's trichrome and TB (toluidine blue) stain; (d-l) rhTGF- $\beta 1-F 2$ and rhBMP-2-treated culture cells. Several nodules of cartilage and bone-like tissue located near the filters were observed. (d) PSH; (e-g, details from zone 2) AB (alcian blue), TB and type II collagen immunohistochemistry; (h-i, details from zone 3) PSH and Goldner's trichrome stain; (j) von Kossa stain; (k) TB; (I) type I collagen immunohistochemistry. Bars, $500 \mu \mathrm{m}$ in $(\mathbf{a}, \mathbf{d}), 200 \mu \mathrm{m}$ in $(\mathbf{b}, \mathbf{c}, \mathbf{e}-\mathbf{i})$ and $100 \mu \mathrm{m}$ in $(\mathbf{j}-\mathbf{l})$.
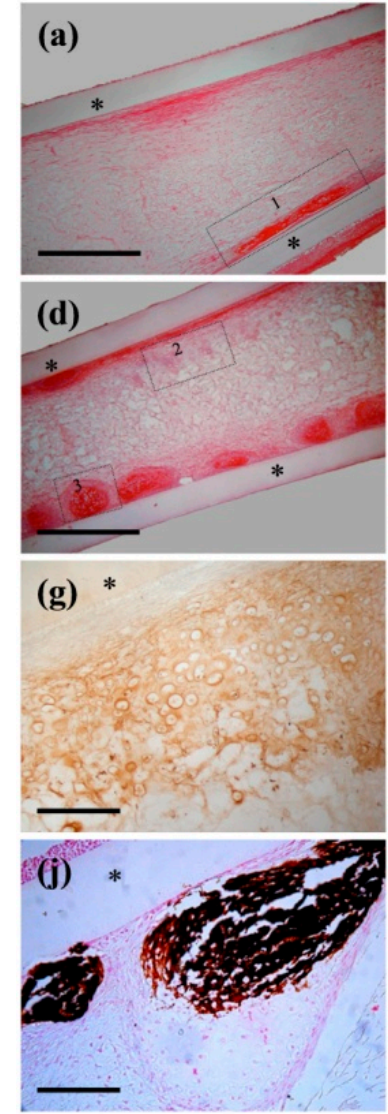
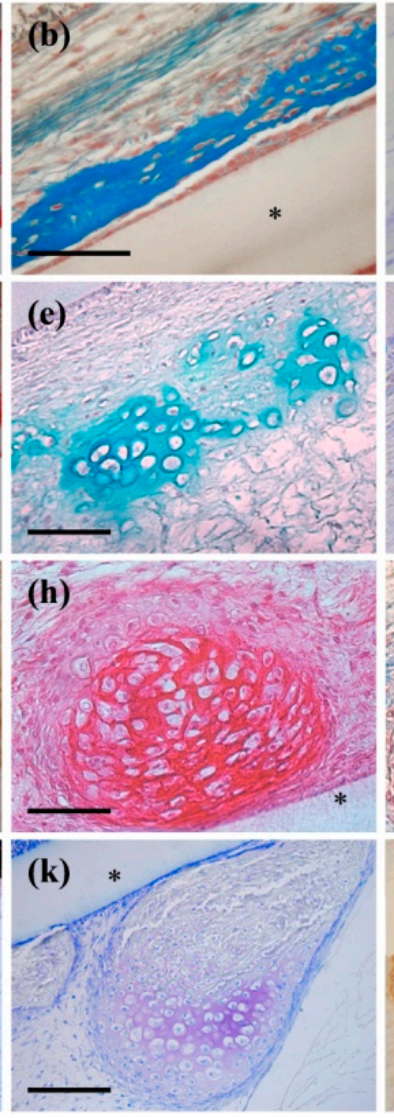
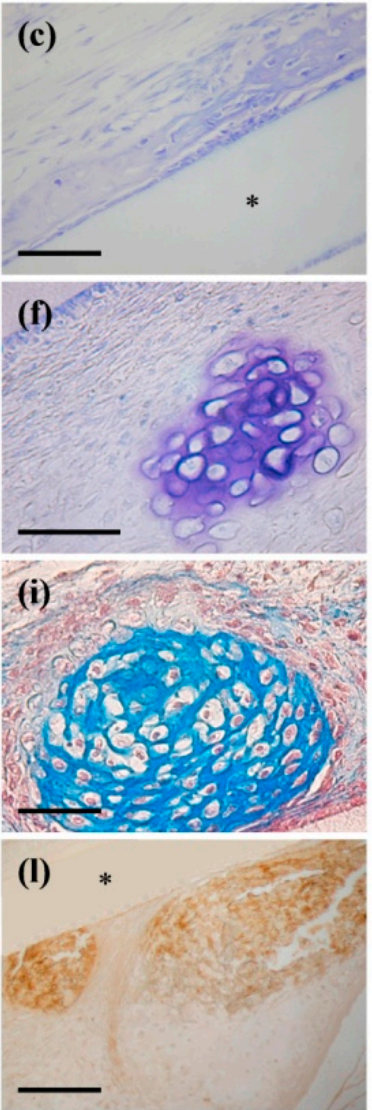

After the 10-day selection period, the surviving cells in the rhTGF- $\beta 1$-F2 test groups proliferated rapidly in response to serum factors, and maximal DNA synthesis levels were observed. Upon the addition of rhBMP-2 and osteoinductive factors, proliferation was evidently downregulated, which is associated with expression of osteoblast functions, including production of ALP, processing of procollagens to collagens, and incremental deposition of a collagenous extracellular matrix [31,32]. As a result, it is widely accepted that high expression of ALP and production of a mineralized matrix serve as useful markers of osteogenesis, where the mineralization marks the final phase of osteoblast phenotypic development [33-35]. Previous reports by our group demonstrated that there was an interesting 
difference in results between the commercial and modified rhTGF- $\beta 1$ [27]. Only rhTGF- $\beta 1-F 2$-treated cells were able to express higher levels of ALP activity and to induce calcium precipitation. Here, the pulse of rhBMP-2 at day 14 significantly increased calcium deposition compared to other conditions. Moreover, this result was consistent with the mineralization of colonies observed in these cultures. All this suggests that the pulse of rhBMP-2 of $4 \mathrm{~h}$ at the end of the proliferation period incorporates an obvious advantage in differentiation and colony mineralization of the osteogenic precursor cell population.

We also analyzed the expression of surface molecule characteristic for mesenchymal, endothelial and hematopoietic lineages using FACS. 3D culture revealed a heterogeneous population of small round cells [36,37]. These results were consistent with our previous studies with human BM-derived cells and commercial rhTGF- $\beta 1$ in the $3 \mathrm{D}$ culture [36], although the immunophenotyping was difficult because of the limited availability of antibodies that show cross-reactivity with the rat. The study of the surface marker profile showed positive cells for hematopoietic (CD34, CD45), mesenchymal (CD29, CD105, CD166, CD271, STRO-1) and endothelial markers (CD34, CD133) [38-42]. Comparing 3D cultures at days 10 and 16, we observed an increase in the expression of mesenchymal cell markers, while EPCs-like populations (CD34+/CD133+/CD45-) significantly decreased over time. Furthermore, our previous results demonstrated that EPCs-like populations decreased in favor of mature endothelial phenotypes (CD146+/KDR+) [43,44], demonstrating that our 3D culture system could be used as a strategy to promote angiogenesis and to improve bone regeneration $[36,45,46]$.

Additionally, we evaluated the expression of pluripotent specific markers by RT-qPCR. Results showed that Nanog, Oct4 and Sox2 were significantly highly expressed in 3D culture at days 10 and 14 but was absent in $\mathrm{ADH}$ cells. These findings are also in agreement with those previously reported by our group [36]. Nanog, Oct4 and Sox 2 target genes, identified in embryonic stem cells (ESCs), are known to overlap substantially, suggesting they collaborate to regulate a common set of genes governing pluripotency, self-renewal, and cell fate determination [47-51]. Thus, it demonstrated that induced expression of Nanog, Oct4 and Sox 2 along or not with other regulatory proteins is enough to reprogram lineage-restricted somatic cell populations [52,53]. These cells, which were called iPS (induced pluripotent stem) cells, exhibit the morphology and growth properties of ESCs and express ESC marker genes [54-56].

For the first time, this study also provided mRNA expression data of genes involved in the osteogenic lineage, as were Bsp, Osx and Oc. Our results confirmed the osteogenic commitment of rhTGF- $\beta 1$-F2-treated cells, and that the pulse of rhBMP-2 significantly increased mRNA levels of Osx and Oc. Osx is an osteoblast-specific transcription factor required for bone formation and mineralization in vivo. In Osx knock-out mice, there is no endochondral or intramembranous bone formation. Moreover, it is known that Osx is essential for the expression of others osteoblast-specific markers such as Bsp, type I collagen, Oc, osteonectin, and osteopontin [56-58].

Taken together, these facts suggest that rhTGF- $\beta 1$-F2 applied to a collagen matrix as vehicle and delivery system could be of advantage in promoting the survival, proliferation, differentiation, and colony mineralization of the osteogenic precursor cell population. The pulse of rhBMP-2 seemed to be beneficial for inducing further differentiation of BM-MSCs towards the osteogenic lineage.

Histological study of 3D culture cells showed significant differences regarding the histogenesis that occurs inside the chambers, depending on the treatment. On the one hand, rhTGF- $\beta 1$-F2-treated cells were only able to generate new bone, which seems to have intramembranous origin because no trace of 
cartilage can be found, such as hypertrophic chondrocytes, cartilage in the process of calcification, or remnants of proteoglycans [1,59]. Nevertheless, rhTGF- $\beta 1-F 2$ and rhBMP-2-treated cells formed abundant cartilage and bone-like nodules, some of them developed via endochondral ossification $[59,60]$. On the other hand, we normally observed cartilage nodules towards the center of the chambers and bone accumulation close to the filter, in agreement with other studies [61-64]. This could be related to the nutritional situation of the different regions of the chambers.

The in vivo analysis proves the efficiency of rhTGF- $\beta 1-F 2$ in selecting a population of precursor cells with chondro-osteogenic potential, and the important role of BMP-2 in the differentiation period in inducing cartilage and bone formation.

\section{Experimental Section}

\subsection{Recombinant Human TGF (Transforming Growth Factor)- $\beta 1$ Fusion Protein}

The full coding region of the rhTGF- $\beta 1$ fusion protein, rhTGF- $\beta 1-F 2$, was generously provided by ME Nimni (University of Southern California, Los Angeles, CA, USA), and details of the technique have been described elsewhere [27-29,65]. Briefly, the cDNA sequence encoding the conserved carboxy-terminal region of rhTGF- $\beta 1$ was engineered to include a high-affinity collagen-binding decapeptide derived from von Willebrand factor bracketed by strategic linkers in frame with an $N$-terminal $6 \times$ His purification tag provided by an expression vector.

\subsection{Isolation of Primary MSCs (Marrow Stromal Cells) and 3D Culture}

Primary cultures of MSCs were established using BM suspensions from rat origin. Rat BM-derived cells were extracted from femurs and tibiae of syngeneic 8-week-old male Fisher 344 rats (Charles River Laboratories, L'Abresles, France) under animal care procedures, conducted in accordance with the guidelines set by the European Community Council Directives (86/609/EEC) and approved by the local ethical committee. The epiphysis was removed and the medullar canal was washed with Dulbecco's modified Eagle's medium (DMEM, Sigma-Aldrich, Madrid, Spain) using a syringe. The medium containing the extracted cells was directed into a Falcon tube (Becton Dickinson, Barcelona, Spain) and the cells were suspended, homogenized, and centrifuged at $400 \mathrm{~g}$ for $10 \mathrm{~min}$.

BM-derived cells were cultured in a 3D environment using a modification of a previously described method [27]. Briefly, a collagen substrate for cell culture was prepared using a solution containing $0.85 \mathrm{mg} / \mathrm{mL}$ rat tail tendon type I collagen (Becton Dickinson), $1 \mathrm{M} \mathrm{NaOH}, 10 \times$ DMEM-F12, $100 \mathrm{U} / \mathrm{mL}$ penicillin, $100 \mu \mathrm{g} / \mathrm{mL}$ streptomycin and $1.25 \mu \mathrm{g} / \mathrm{mL}$ fungizone (all from Sigma-Aldrich) in MilliQ water at pH 7.4. 48-well plates (Nunc, Thermo Fischer Scientific, Hennigsdorf, Germany) were coated with $150 \mu \mathrm{L}$ of this solution and placed at $37{ }^{\circ} \mathrm{C}$ for $30 \mathrm{~min}$ in order for it to solidify into a thin collagen gel matrix. After that, all of the cells were re-suspended in DMEM-F12 and mixed with the collagen solution plus $0.5 \% \mathrm{FBS}$, in the presence of $1 \mathrm{ng} / \mathrm{mL}$ rhTGF- $\beta 1-\mathrm{F} 2$ at a density of $2.5 \times 10^{5}$ cells $/ 250 \mu \mathrm{L}$ collagen/well in 48 -well plates. The culture plates were left $30 \mathrm{~min}$ at $37{ }^{\circ} \mathrm{C}$ to allow the collagen to gel. Then, $250 \mu \mathrm{L} /$ well of culture medium that consisted of DMEM supplemented with $1 \mathrm{ng} / \mathrm{mL}$ rhTGF- $\beta 1-F 2,0.5 \%$ FBS, $2.5 \mathrm{mM}$ L-Glutamine (both from Sigma-Aldrich) and the same amount of penicillin-streptomycin and fungizone as described above were added on top of the gel. 
Cells were incubated in this culture medium containing $0.5 \%$ FBS for 10 days in order to eliminate hematopoietic cells. After the 10-day selection period, the medium was then changed to $10 \% \mathrm{FBS}$ and cells were cultured for an additional 4 days (amplification period). Afterwards, cells were treated with a short pulse of recombinant human BMP-2 (rhBMP-2, R\&D Systems Europe, Abingdon, UK) for $4 \mathrm{~h}$. At the end of the culture, cells were incubated for 2 days in medium supplemented with $10^{-8} \mathrm{M}$ Dexametasone (Dex) and $2 \mathrm{mM} \beta$-glycerophosphate ( $\beta$-GP) (both from Sigma-Aldrich) to help with the osteogenic differentiation. Control cultures were maintained without adding growth factor. Cultures were fed every third day with appropriate fresh medium and maintained at $37{ }^{\circ} \mathrm{C}$ in a humidified atmosphere containing $95 \%$ air and $5 \% \mathrm{CO}_{2}$.

Adherent culture (ADH) was used like a control in RT-qPCR and flow cytometry analysis. BM-derived cells were plated at a concentration of $10^{7}$ cells $/ 75-\mathrm{cm}^{2}$ tissue culture flask and maintained in DMEM containing 10\% FBS, $2.5 \mathrm{mM} \mathrm{L}$-glutamine, $100 \mathrm{U} / \mathrm{mL}$ penicillin, $100 \mu \mathrm{g} / \mathrm{mL}$ streptomycin, and $1.25 \mu \mathrm{g} / \mathrm{mL}$ fungizone. The culture medium was changed two times per week, and the cells were selected by their capacity to attach to the dish surface, discarding the floating cells in the first medium change at $72 \mathrm{~h}$. When culture flasks became near-confluent, cells were detached with $0.25 \%$ trypsin containing $1 \mathrm{mmol} / \mathrm{L}$ EDTA and subsequently replated at $5 \times 10^{3}$ cells $/ \mathrm{cm}^{2}$ for continued passaging.

\subsection{Flow Cytometry Analysis of Cells}

In order to analyze the expression of surface markers characteristic for mesenchymal, endothelial and hematopoietic cells, fluorescence-activated cell sorting (FACS) was performed at days 10 and 16, using specific fluorochrome-conjugated monoclonal antibodies. Rat BM-derived cells were washed twice in FACS buffer consisting of $10 \mathrm{mM}$ hepes (Gibco ${ }^{\circledR} /$ Invitrogen, Barcelona, Spain), $100 \mathrm{U} / \mathrm{mL}$ penicillin, $100 \mu \mathrm{g} / \mathrm{mL}$ streptomycin and $2 \mathrm{mg} / \mathrm{mL}$ bovine serum albumin (Sigma, Madrid, Spain) in Leibovitz's L-15 medium (Gibco). After the washing step, cells aliquots $\left(1 \times 10^{6}\right.$ cells) were incubated in FACS buffer containing monoclonal antibodies against CD29 (BD Pharmigen, Becton Dickinson, Barcelona, Spain), CD34, CD45, CD133 and CD271 (Miltenyi Biotech, Madrid, Spain), CD105 and STRO-1 (R\&D Systems) and CD166 (AbD Serotec, Oxford, UK), or an appropriate isotype control antibody (Sigma-Aldrich). After $30 \mathrm{~min}$ in the dark on ice, cells were washed again in FACS buffer before flow cytometry analysis. One hundred thousand events per sample were analyzed on a MoFlo ${ }^{\circledR}$ SP1338 (DakoCytomation, Glostrup, Denmark) using Summit software. Cells were gated on forward and side scatter to exclude debris and cell aggregates, and dead cells were excluded by 7-Amino-Actinomycin D (7-AAD, BD Pharmigen) staining.

\section{4. $R T-q P C R$ Analysis}

The expression levels of rat pluripotency genes Nanog, Oct4 and Sox2 were analyzed for 3D cultures after 10 and 14 days by RT-qPCR. Moreover, the osteogenesis markers Bsp, Osx and Oc were evaluated at the end of differentiation period (day 16). Reference gene Gapdh was used as positive control. Total RNA was isolated using RNeasy Kit (Qiagen, Valencia, CA, USA) and its quantity and purity were estimated by Nanodrop (Thermo Fischer Scientific). Only samples with an A260/A280 nm ratio between 1.8 and 2.0 were accepted. $1 \mu \mathrm{g}$ of the total RNA sample was used as a template for cDNA synthesis by SuperScript ${ }^{\circledR}$ First-Strand Synthesis System Kit and controls "minus RT" 
were performed to test possible genomic DNA amplification (Invitrogen, Carlsbad, CA, USA). Both protocols were performed following the manufacturer's directions. Primer sequences, accession numbers for rat mRNA and references papers are in Table 2. All primer sequences were designed using Oligo Explorer 1.5 software (GeneLink ${ }^{\mathrm{TM}}$, Hawthorne, NY, USA) and determined through established GenBank sequences.

Table 2. Primer sequences for RT-qPCR with the expected product size.

\begin{tabular}{|c|c|c|c|c|}
\hline $\begin{array}{l}\text { Gene } \\
\text { Name }\end{array}$ & $\begin{array}{l}\text { Accession } \\
\text { Number }\end{array}$ & $\begin{array}{c}\text { Primer Sequence 5'-3' } \\
\text { (Forward, Reverse) } \\
\text { Reference } \\
\end{array}$ & $\begin{array}{c}\text { Theoric/Used } \\
\text { Annealing } \\
\text { Temperature }\left({ }^{\circ} \mathrm{C}\right) \\
\end{array}$ & $\begin{array}{l}\text { Product } \\
\text { Size (bp) }\end{array}$ \\
\hline Nanog & NM_001100781 & $\begin{array}{c}\text { GCCCTGAGAAGAAAGAAGAGAA } \\
\text { TACCTTTGCCTCTGAAACCT } \\
\end{array}$ & $59.3 / 60.0$ & 112 \\
\hline $\begin{array}{c}\text { Oct4 } \\
\text { (Pou5f1) }\end{array}$ & NM_001009178 & $\begin{array}{c}\text { CCCATTTCACCACACTCTACTC } \\
\text { GACAGGAACAGAGGGAAAGG } \\
\text { Han et al. } 2012[66]\end{array}$ & $60.9 / 60.0$ & 68 \\
\hline Sox 2 & NM_001109181 & $\begin{array}{c}\text { ATTACCCGCAGCAAAATGAC } \\
\text { GCGTTAATTTGGATGGGATTGG } \\
\text { Han } \text { et al. } 2012 \text { [66] }\end{array}$ & $59.0 / 60.0$ & 60 \\
\hline $\begin{array}{c}\text { Bsp } \\
\text { (Ibsp) }\end{array}$ & NM_012587 & $\begin{array}{c}\text { ATGAAGGAAAGCGACGAGGA } \\
\text { GTGGAGTTGGTGCTGGTG }\end{array}$ & $60.9 / 60.0$ & 113 \\
\hline $\begin{array}{l}\text { Osx } \\
(\mathrm{Sp} 7)\end{array}$ & NM_001037632 & $\begin{array}{c}\text { CTTTCCCCACTCATTTCCTG } \\
\text { CTAGGCAGGCAGTCAGAAG } \\
\text { Takahashi et al. } 2008 \text { [67] }\end{array}$ & $61.1 / 60.0$ & 90 \\
\hline $\begin{array}{c}\text { Oc } \\
\text { (Bglap) }\end{array}$ & NM_013414 & $\begin{array}{c}\text { ACСCTCTCTCTGCTCACTC } \\
\text { CTTACTGCCCTCCTGCTT } \\
\text { Zhou et al. } 2010[68] \\
\end{array}$ & $61.8 / 60.0$ & 124 \\
\hline Gapdh & NM_017008 & $\begin{array}{c}\text { CATGCCGCCTGGAGAAAC } \\
\text { CCCAGGATGCCCTTTAGT } \\
\text { Han et al. } 2012[66] \\
\end{array}$ & $60.9 / 60.0$ & 88 \\
\hline
\end{tabular}

RT-qPCR was done with SYBR ${ }^{\circledR}$ Premix Ex Taq ${ }^{\mathrm{TM}}$ following the manufacturer guidelines (Takara Bio, Inc., Otsu, Japan). Amplifications were performed and monitored in a 7500 Real-Time PCR System (Applied Biosystems, Madrid, Spain). Optimal quantities of each primer and cDNA dilution were tested for every gene and sample. The PCR amplification conditions were: $10 \mathrm{~s}$ at $95{ }^{\circ} \mathrm{C}$ of an initial denaturation, 40 cycles consisting of $3 \mathrm{~s}$ at $95{ }^{\circ} \mathrm{C}$ and $25 \mathrm{~s}$ at $60{ }^{\circ} \mathrm{C}$. Each cDNA sequence was tested in triplicate and a dissociation melt curve protocol was run after every PCR reaction to determine the specificity of products. The levels of gene expression were determined by the comparative $C_{\mathrm{t}}$ method normalized with the endogenous control (Gapdh, glyceraldehyde 3-phosphate dehydrogenase), and compared to those in ADH cells.

\subsection{Biochemical Assays}

After 10, 14 and 16 days in culture, quantitative measurements of cell number (expressed as DNA amount), ALP activity and calcium content were determined. For determination of DNA amount and ALP activity, cells were lysed with $0.15 \mathrm{M} \mathrm{NaCl}, 3 \mathrm{mM} \mathrm{NaHCO} 3$ and $0.1 \%$ Triton $\mathrm{X}-100$ (all from 
Sigma-Aldrich, St. Louis, MO, USA) in distilled water, $\mathrm{pH} 7.4$, and repeatedly frozen-thawed for three times to disrupt the cell membranes. After that, the cells were sonicated for $30 \mathrm{~s}$ using an ultrasonic homogenizer (Vibra-Cell sonicator, Sonics and Materials, Inc., Newtown, CT, USA). DNA amount was determined by incubating $100 \mu \mathrm{L}$ of cell lysates with $100 \mu \mathrm{L}$ of Hoechst 33285 solution $(1 \mu \mathrm{g} / \mathrm{mL})$ (Sigma-Aldrich). Hoechst 33285 intercalates with DNA and emits fluorescence (maximum at $460 \mathrm{~nm}$ ) when excited with ultraviolet light. Fluorochrome emission was measured at $450 \mathrm{~nm}$ by a fluorescence microplate reader (FL600, Bio-Tek Instruments, Winooski, VT, USA). DNA was determined in reference to a standard curve generated from serial-diluted DNA activated from calf thymus (Sigma-Aldrich). For analysis of ALP activity, aliquots of cell lysates were incubated with p-nitrophenolphosphate (pNPP, Sigma-Aldrich) for $30 \mathrm{~min}$ at $37^{\circ} \mathrm{C}$, and the results were quantified at $405 \mathrm{~nm}$ using a microplate reader $(\mathrm{EL} \times 800$, Bio-Tek Instruments). For determination of calcium levels, the cells were washed with $\mathrm{Ca}^{2+}$ and $\mathrm{Mg}^{2+}$ free PBS and then solubilized with $0.6 \mathrm{~N} \mathrm{HCl}$ (both from Sigma-Aldrich). Measurements were done by colorimetry, using the 587-A calcium assay kit (Sigma-Aldrich), and the colorimetric reaction was read at $570 \mathrm{~nm}$. The absolute calcium concentration was determined according to a standard curve according to the manufacturer's recommendations. All assays were determined in triplicate for each condition and the data are expressed as mean $\pm \mathrm{SD}$.

\subsection{In Vivo Implantation and Histological Study}

One million cells were inoculated into diffusion chambers $(150 \mu \mathrm{L}$ volume. Commercial discs were made of a plastic ring and two Millipore filters of $0.45 \mu \mathrm{m}$ pore size, all from Millipore, Madrid, Spain) and then implanted subcutaneously into syngeneic 10-week-old Fisher 344 rats under anesthesia. Chambers were harvested 4 weeks after implantation and processed for histology. Briefly, they were fixed in Bouin's solution (Panreac, Barcelona, Spain) or 4\% paraformaldehyde (Sigma-Aldrich) and dehydrated in alcohol, embedded in paraffin (Panreac, Barcelona, Spain) and sectioned at $8 \mu \mathrm{m}$ thick. Afterwards, sections were stained with picrosirius-hematoxyline ( $\mathrm{PSH}$, Panreac), a technique that shows specificity for type I collagen, alcian blue (AB, Sigma-Aldrich), that reveals glycosaminaglycans from the cartilage matrix, toluidine blue (TB, Panreac) that exhibits metachromatic reaction with cartilage matrix, Goldner's trichromic (Sigma-Aldrich) that stains mineralized type I collagen fibers and von Kossa (Sigma-Aldrich) that reveals calcium phosphate deposits in black. Additionally, consecutive sections were analysed immunohistochemically for type I and II collagen.

For immunohistochemical analyses, deparaffinised sections were rehydrated and then endogenous peroxidase was blocked with 3\% hydrogen peroxide (Panreac). For type II collagen detection, sections were digested with papain at $0.5 \mathrm{mg} / \mathrm{mL}$ in phosphate buffer $(\mathrm{pH} 4.7)$ for 15 min at $37^{\circ} \mathrm{C}$ (both from Panreac). Afterwards, they were incubated with rabbit polyclonal anti-collagen type I and II antibody (Calbiochem-Novabiochem Co., San Diego, CA, USA) at a 1:60 and 1:200 dilution, respectively, in buffer consisting of Tris-PBS pH 7.8, 0.5\% Triton X-100, 1\% BSA and 5\% sheep serum (all from Sigma-Aldrich) overnight at $4{ }^{\circ} \mathrm{C}$, followed by incubation with goat anti-rabbit IgG (Sigma-Aldrich) diluted 1:50 for $1 \mathrm{~h}$, and PAP-rabbit complex (Dako) diluted 1:200 for $1 \mathrm{~h}$. All incubations were carried out in a humid chamber and sections were washed three times for $5 \mathrm{~min}$ in Tris-PBS between each stage. The PAP complex was visualized by 3,3'-diaminobenzidine tetrahydrochloride (DAB, 
Sigma-Aldrich). After rinsing in distilled water, sections were dehydrated in ascending ethanol solutions, cleared in xylene and mounted. Control sections were incubated without the primary antibody.

\subsection{Statistics}

Means and standard deviations were performed using Sigma Stat software (SPSS Inc., Chicago, IL, USA) with analysis of variance (ANOVA), followed of Tukey post hoc test, after the data passed normality and equal variance tests. Results were considered significantly different at $p>0.05$.

\section{Conclusions}

In conclusion, our results support that rhTGF- $\beta 1-F 2$ is a highly promising factor for expanding BM-derived cells maintaining their properties of stemness during the 10-day selection period and improving their chondrogenic and osteogenic differentiation. The pulse of rhBMP-2 for only $4 \mathrm{~h}$ incorporated a significant advantage in increasing the amount of cartilaginous and bone tissue in vivo. Therefore, BM-derived cells cultured in the 3D collagen matrix in the presence of rhTGF- $\beta 1-F 2$ and rhBMP-2 could be an important therapeutic tool for tissue engineering and regenerative medicine.

\section{Acknowledgments}

This work was supported by grants from the Ministry of Economy and Competitiveness (FIS PI13/00666), the Ministry of Science and Technology (BIO2009-13903-C02-02), and the Andalusian Government (P07-CVI-2781, PAIDI BIO-217, PI-0729-2010). Red de Terapia Celular and CIBER-BBN are an initiative funded by the VI National R\&D\&I Plan 2008-2011, Iniciativa Ingenio 2010, Consolider Program, CIBER Actions, and financed by the Instituto de Salud Carlos III with assistance from the European Regional Development Fund.

\section{Author Contributions}

S.C., G.A.R.-L., and J.A.A. participated in the design and coordination of the study, and drafted the manuscript. S.C. and G.A.R.-L. participated in the data collection, analysis and interpretation. S.C. carried out the samples collection. S.C., J.B., and J.A.A. participated in the revision of manuscript content. All authors read and approved the final manuscript.

\section{Conflicts of Interest}

The authors declare no conflict of interest.

\section{References}

1. Bianco, P.; Cao, X.; Frenette, P.S.; Mao, J.J.; Robey, P.G.; Simmons, P.J.; Wang, C.Y. The meaning, the sense and the significance: Translating the science of mesenchymal stem cells into medicine. Nat. Med. 2013, 19, 35-42.

2. Prockop, D.J. Marrow stromal cells as stem cells for nonhematopoietic tissues. Science 1997, $276,71-74$. 
3. Okano, T.; Dezawa, M. A new age of regenerative medicine: Fusion of tissue engineering and stem cell research. Anat. Rec. (Hoboken) 2014, 297, 4-5.

4. Jiang, Y.; Jahagirdar, B.N.; Reinhardt, R.L.; Schwartz, R.E.; Keene, C.D.; Ortiz-Gonzalez, X.R.; Reyes, M.; Lenvik, T.; Lund, T.; Blackstad, M.; et al. Pluripotency of mesenchymal stem cells derived from adult marrow. Nature 2002, 418, 41-49.

5. Hemmrich, K.; von Heimburg, D.; Cierpka, K.; Haydarlioglu, S.; Pallua, N. Optimization of the differentiation of human preadipocytes in vitro. Differentiation 2005, 73, 28-35.

6. Isern, J.; Méndez-Ferrer, S. Stem cell interactions in a bone marrow niche. Curr. Osteoporos. Rep. 2011, 9, 210-218.

7. Silva, W.A., Jr.; Covas, D.T.; Panepucci, R.A.; Proto-Siqueira, R.; Siufi, J.L.C.; Zanette, D.L.; Santos, A.R.D.; Zago, M.A. The profile of gene expression of human marrow mesenchymal stem cells. Stem Cells 2003, 21, 661-669.

8. Das, M.; Sundell, I.B.; Koka, P.S. Adult mesenchymal stem cells and their potency in the cell-based therapy. J. Stem Cells 2013, 8, 1-16.

9. Hofstetter, C.P.; Schwarz, E.J.; Hess, D.; Widenfalk, J.; el Manira, A.; Prockop, D.J.; Olson, L. Marrow stromal cells form guiding strands in the injured spinal cord and promote recovery. Proc. Natl. Acad. Sci. USA 2002, 99, 2199-2204.

10. Horwitz, E.M.; Gordon, P.L.; Koo, W.K.K.; Marx, J.C.; Neel, M.D.; McNall, R.Y.; Muul, L.; Hofmann, T. Isolated allogeneic bone marrow-derived mesenchymal cells engraft and stimulate growth in children with osteogenesis imperfecta: Implications for cell therapy of bone. Proc. Natl. Acad. Sci. USA 2002, 99, 8932-8937.

11. Chen, T.L. Inhibition of growth and differentiation of osteoprogenitors in mouse bone marrow stromal cell cultures by increased donor age and glucocorticoid treatment. Bone 2004, 35, 83-95.

12. Shenaq, D.S.; Rastegar, F.; Petkovic, D.; Zhang, B.Q.; He, B.C.; Chen, L.; Zuo, G.W.; Luo, Q.; Shi, Q.; Wagner, E.R.; et al. Mesenchymal progenitor cells and their orthopedic applications: Forging a path towards clinical trials. Stem Cells Int. 2010, 2010, doi:10.4061/2010/519028.

13. Centrella, M.; Horowitz, M.C.; Wozney, J.M.; McCarthy, T.L. Transforming growth factor-beta gene family members and bone. Endocr. Rev. 1994, 15, 27-39.

14. Chen, G.; Deng, C.; Li, Y.P. TGF- $\beta$ and BMP signaling in osteoblast differentiation and bone formation. Int. J. Biol. Sci. 2012, 8, 272-288.

15. Long, M.W.; Robinson, J.A.; Ashcraft, E.A.; Mann, K.G. Regulation of human bone marrow-derived osteoprogenitor cells by osteogenic growth factors. J. Clin. Investig. 1995, 95, 881-887.

16. Lu, L.; Yaszemski, M.J.; Mikos, A.G. TGF-beta1 release from biodegradable polymer microparticles: Its effects on marrow stromal osteoblast function. J. Bone Jt. Surg. Am. 2001, 83- $A$ (Suppl. 1), S82-S91.

17. Zhao, L.; Hantash, B.M. TGF- $\beta 1$ regulates differentiation of bone marrow mesenchymal stem cells. Vitam. Horm. 2011, 87, 127-141.

18. Murphy, C.M.; O’Brien, F.J.; Little, D.G.; Schindeler, A. Cell-scaffold interactions in the bone tissue engineering triad. Eur. Cell Mater. 2013, 26, 120-132.

19. Roberts, A.B.; Sporn, M.B. Physiological actions and clinical applications of transforming growth factor-beta (TGF-beta). Growth Factors 1993, 8, 1-9. 
20. Gazit, D.; Zilberman, Y.; Turgeman, G.; Zhou, S.; Kahn, A. Recombinant TGF-beta1 stimulates bone marrow osteoprogenitor cell activity and bone matrix synthesis in osteopenic, old male mice. J. Cell. Biochem. 1999, 73, 379-389.

21. Moxham, J.P.; Kibblewhite, D.J.; Dvorak, M.; Perey, B.; Tencer, A.F.; Bruce, A.G.; Strong, D.M. TGF-beta 1 forms functionally normal bone in a segmental sheep tibial diaphyseal defect. J. Otolaryngol. 1996, 25, 388-392.

22. Walsh, S.; Jefferiss, C.; Stewart, K.; Beresford, J.N. TGFbetal limits the expansion of the osteoprogenitor fraction in cultures of human bone marrow stromal cells. Cell Tissue Res. 2003, $311,187-198$.

23. Urist, M.R. Bone: Formation by autoinduction. Science 1965, 150, 893-899.

24. Reddi, A.H. Role of morphogenetic proteins in skeletal tissue engineering and regeneration. Nat. Biotechnol. 1998, 16, 247-252.

25. Wozney, J.M.; Rosen, V. Bone morphogenetic protein and bone morphogenetic protein gene family in bone formation and repair. Clin. Orthop. Relat. Res. 1998, 346, 26-37.

26. Tachi, K.; Takami, M.; Sato, H.; Mochizuki, A.; Zhao, B.; Miyamoto, Y.; Tsukasaki, H.; Inoue, T.; Shintani, S.; Koike, T.; et al. Enhancement of bone morphogenetic protein-2-induced ectopic bone formation by transforming growth factor- $\beta 1$. Tissue Eng. A 2011, 17, 597-606.

27. Andrades, J.A.; Han, B.; Becerra, J.; Sorgente, N.; Hall, F.L.; Nimni, M.E. A recombinant human TGF-betal fusion protein with collagen-binding domain promotes migration, growth, and differentiation of bone marrow mesenchymal cells. Exp. Cell Res. 1999, 250, 485-498.

28. Andrades, J.A.; Becerra, J. Type I collagen combined with a recombinant TGF- $\beta$ serves as a scaffold for mesenchymal stem cells. In Advances in Skeletal Reconstruction Using Bone Morphogenetic Proteins; World Scientific: Singapore, Singapore, 2002; pp. 281-309.

29. Andrades, J.A.; Han, B.; Nimni, M.E.; Ertl, D.C.; Simpkins, R.J.; Arrabal, M.P.; Becerra, J. A modified rhTGF-betal and rhBMP-2 are effective in initiating a chondro-osseous differentiation pathway in bone marrow cells cultured in vitro. Connect. Tissue Res. 2003, 44, 188-197.

30. Becerra, J.; Guerado, E.; Claros, S.; Alonso, M.; Bertrand, M.L.; González, C.; Andrades, J.A. Autologous human-derived bone marrow cells exposed to a novel TGF-betal fusion protein for the treatment of critically sized tibial defect. Regen. Med. 2006, 1, 267-278.

31. Neve, A.; Corrado, A.; Cantatore, F.P. Osteoblast physiology in normal and pathological conditions. Cell Tissue Res. 2011, 343, 289-302.

32. Reilly, G.C.; Radin, S.; Chen, A.T.; Ducheyne, P. Differential alkaline phosphatase responses of rat and human bone marrow derived mesenchymal stem cells to $45 \mathrm{~S} 5$ bioactive glass. Biomaterials 2007, 28, 4091-4097.

33. Birmingham, E.; Niebur, G.L.; McHugh, P.E.; Shaw, G.; Barry, F.P.; McNamara, L.M. Osteogenic differentiation of mesenchymal stem cells is regulated by osteocyte and osteoblast cells in a simplified bone niche. Eur. Cell Mater. 2012, 23, 13-27.

34. Hoemann, C.D.; el-Gabalawy, H.; McKee, M.D. In vitro osteogenesis assays: Influence of the primary cell source on alkaline phosphatase activity and mineralization. Pathol. Biol. 2009, $57,318-323$. 
35. Huang, Z.; Nelson, E.R.; Smith, R.L.; Goodman, S.B. The sequential expression profiles of growth factors from osteoprogenitors [correction of osteroprogenitors] to osteoblasts in vitro. Tissue Eng. 2007, 13, 2311-2320.

36. Claros, S.; Rodríguez-Losada, N.; Cruz, E.; Guerado, E.; Becerra, J.; Andrades, J.A. Characterization of adult stem/progenitor cell populations from bone marrow in a three-dimensional collagen gel culture system. Cell Transplant. 2012, 21, 2021-2032.

37. Minguell, J.J.; Fierro, F.A.; Epuñan, M.J.; Erices, A.A.; Sierralta, W.D. Nonstimulated human uncommitted mesenchymal stem cells express cell markers of mesenchymal and neural lineages. Stem Cells Dev. 2005, 14, 408-414.

38. Beyer Nardi, N.; da Silva Meirelles, L. Mesenchymal stem cells: Isolation, in vitro expansion and characterization. Handb. Exp. Pharmacol. 2006, 174, 249-282.

39. Dominici, M.; le Blanc, K.; Mueller, I.; Slaper-Cortenbach, I.; Marini, F.; Krause, D.; Deans, R.; Keating, A.; Prockop, D.; Horwitz, E. Minimal criteria for defining multipotent mesenchymal stromal cells. The International Society for Cellular Therapy position statement. Cytotherapy 2006, 8, 315-317.

40. Jones, E.A.; Kinsey, S.E.; English, A.; Jones, R.A.; Straszynski, L.; Meredith, D.M.; Markham, A.F.; Jack, A.; Emery, P.; McGonagle, D. Isolation and characterization of bone marrow multipotential mesenchymal progenitor cells. Arthritis Rheum. 2002, 46, 3349-3360.

41. Kolf, C.M.; Cho, E.; Tuan, R.S. Mesenchymal stromal cells. Biology of adult mesenchymal stem cells: Regulation of niche, self-renewal and differentiation. Arthritis Res. Ther. 2007, 9, 204.

42. Rasmusson, I. Immune modulation by mesenchymal stem cells. Exp. Cell Res. 2006, 312, 2169-2179.

43. Smadja, D.M.; Mauge, L.; Sanchez, O.; Silvestre, J.S.; Guerin, C.; Godier, A.; Henno, P.; Gaussem, P.; Israël-Biet, D. Distinct patterns of circulating endothelial cells in pulmonary hypertension. Eur. Respir. J. 2010, 36, 1284-1293.

44. Untergasser, G.; Koeck, R.; Wolf, D.; Rumpold, H.; Ott, H.; Debbage, P.; Koppelstaetter, C.; Gunsilius, E. CD34+/CD133- circulating endothelial precursor cells (CEP): Characterization, senescence and in vivo application. Exp. Gerontol. 2006, 41, 600-608.

45. Li, R.; Stewart, D.J.; von Schroeder, H.P.; Mackinnon, E.S.; Schemitsch, E.H. Effect of cell-based VEGF gene therapy on healing of a segmental bone defect. J. Orthop. Res. 2009, 27, 8-14.

46. Matsumoto, T.; Kuroda, R.; Mifune, Y.; Kawamoto, A.; Shoji, T.; Miwa, M.; Asahara, T.; Kurosaka, M. Circulating endothelial/skeletal progenitor cells for bone regeneration and healing. Bone 2008, 43, 434-439.

47. Chambers, I.; Tomlinson, S.R. The transcriptional foundation of pluripotency. Development 2009, 136, 2311-2322.

48. Mitsui, K.; Tokuzawa, Y.; Itoh, H.; Segawa, K.; Murakami, M.; Takahashi, K.; Maruyama, M.; Maeda, M.; Yamanaka, S. The homeoprotein Nanog is required for maintenance of pluripotency in mouse epiblast and ES cells. Cell 2003, 113, 631-642.

49. Rodda, D.J.; Chew, J.L.; Lim, L.H.; Loh, Y.H.; Wang, B.; Ng, H.H.; Robson, P. Transcriptional regulation of nanog by OCT4 and SOX2. J. Biol. Chem. 2005, 280, 24731-24737. 
50. Yoon, D.S.; Kim, Y.H.; Jung, H.S.; Paik, S.; Lee, J.W. Importance of Sox2 in maintenance of cell proliferation and multipotency of mesenchymal stem cells in low-density culture. Cell Prolif. 2011, 44, 428-440.

51. Zheng, C.; Yang, S.; Guo, Z.; Liao, W.; Zhang, L.; Yang, R.; Han, Z.C. Human multipotent mesenchymal stromal cells from fetal lung expressing pluripotent markers and differentiating into cell types of three germ layers. Cell Transplant. 2009, 18, 1093-1109.

52. Navarro, P.; Festuccia, N.; Colby, D.; Gagliardi, A.; Mullin, N.P.; Zhang, W.; Karwacki-Neisius, V.; Osorno, R.; Kelly, D.; Robertson, M.; et al. OCT4/SOX2-independent Nanog autorepression modulates heterogeneous Nanog gene expression in mouse ES cells. EMBO J. 2012, 31, 4547-4562.

53. Wang, Z.; Oron, E.; Nelson, B.; Razis, S.; Ivanova, N. Distinct lineage specification roles for NANOG, OCT4, and SOX2 in human embryonic stem cells. Cell Stem Cell 2012, 10, 440-454.

54. Takahashi, K.; Yamanaka, S. Induction of pluripotent stem cells from mouse embryonic and adult fibroblast cultures by defined factors. Cell 2006, 126, 663-676.

55. Yu, J.; Vodyanik, M.A.; Smuga-Otto, K.; Antosiewicz-Bourget, J.; Frane, J.L.; Tian, S.; Nie, J.; Jonsdottir, G.A.; Ruotti, V.; Stewart, R.; et al. Induced pluripotent stem cell lines derived from human somatic cells. Science 2007, 318, 1917-1920.

56. Zhao, H.; Li, Y.; Jin, H.; Xie, L.; Liu, C.; Jiang, F.; Luo, Y.; Yin, G.; Li, Y.; Wang, J.; et al. Rapid and efficient reprogramming of human amnion-derived cells into pluripotency by three factors OCT4/SOX2/NANOG. Differentiation 2010, 80, 123-129.

57. Nakashima, K.; Zhou, X.; Kunkel, G.; Zhang, Z.; Deng, J.M.; Behringer, R.R.; de Crombrugghe, B. The novel zinc finger-containing transcription factor osterix is required for osteoblast differentiation and bone formation. Cell 2002, 108, 17-29.

58. Nishio, Y.; Dong, Y.; Paris, M.; O’Keefe, R.J.; Schwarz, E.M.; Drissi, H. Runx2-mediated regulation of the zinc finger Osterix/Sp7 gene. Gene 2006, 372, 62-70.

59. Scotti, C.; Tonnarelli, B.; Papadimitropoulos, A.; Scherberich, A.; Schaeren, S.; Schauerte, A.; Lopez-Rios, J.; Zeller, R.; Barbero, A.; Martin, I. Recapitulation of endochondral bone formation using human adult mesenchymal stem cells as a paradigm for developmental engineering. Proc. Natl. Acad. Sci. USA 2010, 107, 7251-7256.

60. Van den Bos, T.; Speijer, D.; Bank, R.A.; Brömme, D.; Everts, V. Differences in matrix composition between calvaria and long bone in mice suggest differences in biomechanical properties and resorption: Special emphasis on collagen. Bone 2008, 43, 459-468.

61. Alonso, M.; Claros, S.; Becerra, J.; Andrades, J.A. The effect of type I collagen on osteochondrogenic differentiation in adipose-derived stromal cells in vivo. Cytotherapy 2008, 10, 597-610.

62. Andrades, J.A.; Santamaría, J.A.; Nimni, M.E.; Becerra, J. Selection and amplification of a bone marrow cell population and its induction to the chondro-osteogenic lineage by rhOP-1: An in vitro and in vivo study. Int. J. Dev. Biol. 2001, 45, 689-693.

63. Ashton, B.A.; Allen, T.D.; Howlett, C.R.; Eaglesom, C.C.; Hattori, A.; Owen, M. Formation of bone and cartilage by marrow stromal cells in diffusion chambers in vivo. Clin. Orthop. Relat. Res. 1980, 151, 294-307. 
64. Claros, S.; Alonso, M.; Becerra, J.; Andrades, J.A. Selection and induction of rat skeletal muscle-derived cells to the chondro-osteogenic lineage. Cell. Mol. Biol. 2008, 54, 1-10.

65. Gordon, E.M.; Skotzko, M.; Kundu, R.K.; Han, B.; Andrades, J.; Nimni, M.; Anderson, W.F.; Hall, F.L. Capture and expansion of bone marrow-derived mesenchymal progenitor cells with a transforming growth factor-beta1-von Willebrand's factor fusion protein for retrovirus-mediated delivery of coagulation factor IX. Hum. Gene Ther. 1997, 8, 1385-1394.

66. Han, S.; Zhao, Y.; Xiao, Z.; Han, J.; Chen, B.; Chen, L.; Dai, J. The three-dimensional collagen scaffold improves the stemness of rat bone marrow mesenchymal stem cells. J. Genet. Genomics 2012, 39, 633-641.

67. Takahashi, T.; Kamiya, N.; Kawabata, N.; Takagi, M. The effect of retinoic acid on a zinc finger transcription factor, AJ18, during differentiation of a rat clonal preosteoblastic cell line, ROB-C20, into osteoblasts. Arch. Oral Biol. 2008, 53, 87-94.

68. Zhou, Y.; Guan, X.X.; Zhu, Z.L.; Guo, J.; Huang, Y.C.; Hou, W.W.; Yu, H.Y. Caffeine inhibits the viability and osteogenic differentiation of rat bone marrow-derived mesenchymal stromal cells. Br. J. Pharmacol. 2010, 161, 1542-1552.

(C) 2014 by the authors; licensee MDPI, Basel, Switzerland. This article is an open access article distributed under the terms and conditions of the Creative Commons Attribution license (http://creativecommons.org/licenses/by/3.0/). 